\begin{tabular}{|c|c|}
\hline Postprint Version & 1.0 \\
\hline Journal website & http://www.ingentaconnect.com \\
\hline Pubmed link & $\begin{array}{l}\text { http://www.ncbi.nlm.nih.gov/entrez/query.fcgi?cmd=Retrieve\&db=pubmed\&dop } \\
\mathrm{t}=\text { Abstract\&list }{ }^{\circ} \text { uids=12974549\&query }{ }^{\circ} \mathrm{hl}=29 \& \text { itool=pubmed } \\
\end{array}$ \\
\hline DOI & 10.1023/A:1025337616327 \\
\hline
\end{tabular}

\title{
METHODS
}

\section{Heterogeneous case definitions used for the surveillance of influenza in Europe}

\author{
J.F. Aguilera ${ }^{1}$, W.J. PAget ${ }^{2}$, A. Mosnier ${ }^{3}$, M.L. HeiJnen ${ }^{4}$, H. UPHOFF ${ }^{5}$, J. VAN DER VeLden ${ }^{2}$, T. \\ VEGA $^{6} \&$ J.M. WATSON ${ }^{1}$
}

1 Respiratory Division, Communicable Disease Surveillance Centre, Public Health Laboratory Service, London, United Kingdom;

2 European Influenza Surveillance Scheme (EISS), Netherlands Institute for Health Services Research (NIVEL), Utrecht;

3 Groupes ReIgionaux d'Observation de la Grippe GROG coordination centre, Open Rome, Paris,

France;

4 Rijksinstituut voor Vollksgezondheid en Milieu (RIVM), Bilthoven, The Netherlands;

5 German Green Cross, Service of Epidemiology, Marburg, Germany;

6 Servicio de Epidemiología, Consejerı́a de Sanidad y Bienestar Social, Junta de Castilla y León, Valladolid, Spain

\begin{abstract}
.
We reviewed the case definitions used by 21 influenza sentinel-based surveillance networks in Western Europe. Two clinical syndromes were used with a wide range of case definitions that nevertheless shared common criteria. Although there is currently no international consensus, efforts are being undertaken to standardise influenza case definitions in Europe.
\end{abstract}

Influenza infection is characterised by an extremely varied clinical syndrome, which partly explains why case definitions used for the surveillance of influenza vary worldwide [1, 2]. Exchange of information and collaboration on influenza surveillance between countries in Western Europe has been facilitated by the European 'Groupes Re' gionaux d'Observation de la Grippe' (EuroGROG) and, since 1996, by the 'European Influenza Surveillance Scheme' (EISS). An added value of exchanging data at the European level is that it complements the information available from national influenza surveillance [3]. However, the use of varying case definitions could limit the comparability of the surveillance between different countries. One option to improve comparability of data shared at European level is to use standardised case definitions. We have therefore reviewed the case definitions currently used to measure influenza activity in Western Europe.

A questionnaire addressing surveillance practices, including the use of a case definition, was sent in October 2000 to (1) all national influenza surveillance coordination centres participating in either EISS or EuroGROG ( $\mathrm{n}=31$ ), and (2) an additional French influenza surveillance coordination centre called 'sentinelles' and based at Unit 444 of the 'Institut National de la Sante' et de la Recherche Me' dicale' (INSERM).

Twenty-two (22/32, 69\%) national coordination centres completed a questionnaire; in most of the cases an epidemiologist and/or a virologist from the coordination centre completed the questionnaire; 21 reported coordinating a sentinel practitioner-based surveillance network (called 'networks' in this article). Networks measured influenza activity by collecting information on the incidence of cases 
presenting with (1) 'influenza-like illness' $(\mathrm{n}=15)$, of which 12 had a written case definition, (2) 'acute respiratory infection' $(\mathrm{n}=3)$, of which two had a definition, and (3) either of the two above $(\mathrm{n}=$ 3 ), of which one had both syndromes defined, one had only one defined, and one had none defined (Table 1).

\section{[ TABLE 1 ]}

The most common symptoms used in the case definitions of 'influenza-like illness' were (a) fever (n $=14)$ of which eight defined as a temperature equal or above $38^{\circ} \mathrm{C}(\mathrm{n}=1)$, above $38^{\circ} \mathrm{C}(\mathrm{n}=6)$ or 39 ${ }^{\circ} \mathrm{C}(\mathrm{n}=1)$, (b) myalgia ( $\left.\mathrm{n}=12\right)$, (c) 'sudden onset' $(\mathrm{n}=10)$ of which two defined as 'within 12 hours', (d) cough $(n=10)$. Other symptoms used were pharyngitis or 'sore throat' $(n=6)$, headache $(n=5)$, general or thoracic pain $(n=5)$, chills $(n=5)$, rhinitis $(n=4)$, arthralgia $(n=3)$, weakness $(n=3)$, prostration $(n=2)$, or stiffness $(n=1)$. A 'contact with a case', or a 'context of influenza epidemic' was used in two networks each. Generic terms used were respiratory 'symptoms', 'affection' or 'manifestation' ( $n=5)$, 'respiratory infections' $(n=1)$, or 'systemic symptoms' $(n=1)$. Only two networks used an international case definition for measuring the incidence of 'influenza-like illness' [4].

The case definitions used for 'acute respiratory infection' included (1) fever (not defined) either as an optional ( $n=2)$ or mandatory ( $n=1)$ criteria, (2) one of each of the following criteria: headache pharyngitis, bronchitis, pneumonia, 'sudden onset' (not defined), and the length of symptoms (1 or 2 weeks), and (3) an 'absence of other diagnosis' $(n=1)$. Some case definitions did not mention specific symptoms but left open inclusion of symptoms under the generic terms of 'respiratory symptoms' ( $\mathrm{n}=$ 1) or 'respiratory infections' $(n=2)$.

This descriptive study outlines the wide range of case definitions of the two different clinical syndromes that were being used to measure influenza activity in 21 European surveillance networks. Although case definitions often differed, even sometimes within two networks in one country, the majority of networks were using common symptoms (e.g. fever, cough, sudden onset or myalgia), or common generic terms (respiratory 'affection' or 'infection'). It is noteworthy that among the six networks that reported not using a case definition for either 'influenza- like illness' or 'acute respiratory infection', some had provided their sentinel practitioners with guidelines where a case of influenza was described.

Although networks shared common criteria to measure influenza activity across Europe, there are still some variations. Some networks used criteria not describing a symptom (e.g. an 'absence of other diagnosis') or criteria varying with the environment (a 'contact with a case' or a 'context of epidemic'), while other networks did not use these criteria. Additionally, terms used for criteria such as 'fever' or 'sudden onset', when not defined, could have different interpretations for sentinel practitioners and could therefore result in variation in the measurement of influenza activity. One could also question whether some criteria are actually applied in sentinel practices, such as for example 'a rise in rectal temperature of $>38^{\circ} \mathrm{C}$ '.

We acknowledge two main limitations to this study. First, the questionnaire was completed by one (or sometimes two) people at the national coordination centre whose views may not be representative of the views of those who run the surveillance system on a day-to-day basis. Second, this study did not collect information on (1) the extent to which sentinel practitioners apply the case definition set at the coordinating level when reporting influenza cases, (2) the 11 European networks for which a questionnaire was not completed.

A majority of networks collected information on the incidence of 'influenza-like illness', which is consistent with what is being reported in some surveillance networks outside of Europe [1, 5-8]. This clinical syndrome is generally more specific but less sensitive to measure influenza activity than the syndrome 'acute respiratory infection'. Although there was not always a clear distinction between the case definitions of these two syndromes in the participating networks, the clinical morbidity rates shared at a European level showed a marked difference between networks reporting 'influenza-like illness' and those reporting 'acute respiratory infection', the latter having rates constantly lower [3].

Although a number of international case definitions exist such as those of the World Health Organisation (WHO) or the 'International Classification of Health Problems in Primary Care', none is 
uniformly applied worldwide in surveillance networks $[9,10]$. This was reflected in our study where most European networks did not use an international case definition, and none used the WHO one. There is currently no international consensus on what should be the case definition of influenza, and the pros and cons of the level of sensitivity and specificity that should be achieved have not yet been fully explored. The choices, and in particular the levels of sensitivity and specificity expected from surveillance, depend on different objectives and presuppositions given by the particular characteristics of the national health care system. This can explain why some networks decided to report the incidence of either 'acute respiratory infections' or 'influenza-like illnesses'. The range of case definitions used in Europe can also be partly explained by historical reasons, most European networks having defined their own influenza case definitions primarily for domestic use only. There was until recently no effort to standardise the case definitions in Europe.

The reporting of data at a European level using a common case definition has been a requirement of the European Commission (EC) since 1998 [11]. By the end of 2002, all networks are expected to define a case of 'influenza-like illness' as follows: 'clinical picture compatible with influenza e.g. sudden onset of disease, cough, fever $>38^{\circ} \mathrm{C}$, muscle and/or headache'. Such a standardised case definition was intended to 'ensure comparability and compatibility of data' [11]. In fact, most of the case definitions used by participants in this survey were compatible with this sensitive case definition, and therefore would comply with the EC requirements.

Even if a standardised cased definition was applied in Europe, following EC recommendations to facilitate exchange and comparison of information, comparability may not be fully achieved because of differences in the way European health care systems are organised (networks that would stop collecting cases of 'acute respiratory infections' and began collecting cases of 'influenza-like illness' instead could be faced with (1) a loss in sensitivity that would affect the early warning capacity of the surveillance system, and (2) difficulties in using historical time series data e.g. for modelling or for the establishment of epidemic thresholds of influenza activity. These consequences could be reduced if networks were to continue collecting cases based on their own national case definition additionally to a standardised one, but having two case definitions would result in an increased workload for both sentinel practitioners and coordinators, which may not be accepted.

In this context, approaches are being explored within network members of the EISS project to standardise case definitions. First, networks could be asked to use the EC case definition, keeping in mind disadvantages of changing or adding a case definition Second, EISS is working - in collaboration with WHO - to harmonise key surveillance indicators in Europe, which will include influenza case definition. Finally, EISS is evaluating other options such as the conversion of national clinical morbidity rates into a common European index of clinical influenza activity [13]. 
Aguilera, J.F., Paget, W.J., Mosnier, A., Heijnen, M.L., Uphoff, H., Velden, J. van der

Heterogeneous case definitions used for the surveillance of influenza in Europe.

European Journal of Epidemiology: 18, 2003, nr. 8, p. 751-754

\section{TABLES}

Table 1. 'Influenza-like illness' and 'acute respiratory infection' case definitions by participant surveillance networks

\begin{tabular}{|c|c|c|}
\hline $\begin{array}{l}\text { Surveillance } \\
\text { networks }\end{array}$ & 'Influenza-like illness' case definitions & $\begin{array}{l}\text { 'Acute respiratory infection' } \\
\text { case definitions }\end{array}$ \\
\hline Belgium & $\begin{array}{l}\text { Sudden onset with fever, myalgia and respiratory } \\
\text { symptoms (cough or thoracic pain) }\end{array}$ & $\begin{array}{l}\text { Any infection involving the } \\
\text { respiratory tract, with or without } \\
\text { fever, which lasts } 1-2 \text { weeks }\end{array}$ \\
\hline Czech Republic & & No case definition used \\
\hline Denmark & $\begin{array}{l}\text { Sudden onset of disease with fever, myalgia and } \\
\text { symptoms of respiratory infection }\end{array}$ & \\
\hline England & No case definition used & \\
\hline France 'GROG' & & $\begin{array}{l}\text { Sudden onset of respiratory } \\
\text { symptoms with infection } \\
\text { context (fever, headaches), } \\
\text { in the absence of other diagnosis }\end{array}$ \\
\hline France 'sentinelles' & $\begin{array}{l}\text { Sudden onset of fever }\left(>39^{\circ} \mathrm{C}\right) \text { with respiratory } \\
\text { symptoms and stiffness, myalgia. }\end{array}$ & \\
\hline Germany & & $\begin{array}{l}\text { Acute pharyngitis, acute } \\
\text { bronchitis or pneumonia, } \\
\text { with or without fever }\end{array}$ \\
\hline Iceland & No answer (not a sentinel practitioner-based network) & \\
\hline Ireland & $\begin{array}{l}\text { Sudden onset of symptoms with a temperature of } 38^{\circ} \mathrm{C} \text { or } \\
\text { more in the absence of any other disease with at least } 2 \\
\text { of the following: headache, myalgia, sore throat, dry cough }\end{array}$ & \\
\hline Italy & $\begin{array}{l}\text { Sudden onset of symptoms, with temperature }>38^{\circ} \mathrm{C} \text {, plus } \\
\text { at least } 1 \text { systemic symptom and at least } 1 \text { respiratory symptom }\end{array}$ & \\
\hline Latvia & $\begin{array}{l}\text { Every illness characterised by sudden onset of fever }\left(>38^{\circ} \mathrm{C}\right) \\
\text { with respiratory symptoms (dry cough and sore throat), } \\
\text { headache and/or myalgia }\end{array}$ & \\
\hline The Netherlands & Pel criteria ${ }^{\mathrm{a}}$ & \\
\hline Norway & $\begin{array}{l}\text { A patient with clear general symptoms, primarily acute } \\
\text { fever }>38{ }^{\circ} \mathrm{C} \text {, headache, muscle ache, and in addition } \\
\text { a dry cough }\end{array}$ & \\
\hline Poland & No case definition used & \\
\hline Portugal & ICHPPC-2-D definition ${ }^{\mathrm{b}}$ & \\
\hline Scotland & No case definition used & No case definition used \\
\hline Slovakia & $\begin{array}{l}\text { Sudden onset and fever with (1) at least } 1 \text { respiratory } \\
\text { symptoms; cough, rhinitis, sore throat, and (2) at least } \\
1 \text { general symptoms: headache, joint ache, chills, malaise }\end{array}$ & \\
\hline Slovenia & $\begin{array}{l}\text { Sudden onset of fever }\left(>38^{\circ} \mathrm{C}\right) \text { with general weakness, } \\
\text { muscle and joint pain, dry cough and symptoms of } \\
\text { upper respiratory tract affection }\end{array}$ & No case definition used \\
\hline Spain & ICHPPC-2-D case definition ${ }^{\mathrm{b}}$ & \\
\hline Sweden & No case definition used & \\
\hline Switzerland & $\begin{array}{l}\text { Respiratory illness with fever }>38^{\circ} \mathrm{C} \text {, myalgia, general pain, } \\
\text { chills, anorexia (optional symptoms are: cough, rhinitis } \\
\text { and arthralgia) }\end{array}$ & \\
\hline Wales & Upper respiratory tract symptoms, fever, chills, myalgia, cough & \\
\hline
\end{tabular}

${ }^{\text {a }}$ Pel criteria [12]. An acute onset (i.e. at most a prodromal stage of 3-4 days), accompanied by a rise in rectal temperature of $>38{ }^{\circ} \mathrm{C}$, and at least one of the following symptoms: cough, coryza, sore throat, frontal headache, retrosternal pain, myalgia.

${ }^{b}$ International Classification of Health Problems in Primary Care [10]. ILI: at least one of the following characteristics: (1) Influenza virus culture positive or serological evidence of influenza virus infection. (2) Context of influenza epidemic, plus 4 of the criteria in 3. (3) Six of the following criteria: sudden onset (within 12 hours), cough, fever, chills, prostration and weakness, myalgia or general pain, rhinitis, pharyngitis, contact with a case. 


\section{REFERENCES}

1. Boivin G, Hardy I, Tellier G, Maziade J. Predicting influenza infections during epidemics with use of a clinical case definition. Clin Infect Dis 2000; 31(5): 1166-1169.

2. Falcao IM, de Andrade HR, Santos AS, Paixao MT, Falcao JM. Programme for the surveillance of influenza in Portugal: Results of the period 1990-1996. J Epidemiol Community Health 1998; 52 (Suppl 1): 39S- 42S.

3. European Influenza Surveillance Scheme, Netherlands Institute for Health Services Research. Annual report: 2000-2001 influenza season. Utrecht, the Netherlands, December 2001.

4. International Classification of Health Problems in Primary Care. New York, NY: Oxford University Press Inc, 1983, p. 487.

5. WHO. Influenza case definition. Available from <http://www.who.int/emcdocuments/surveillance/docs/ whocdscsrisr992.html/15Influenza.htm>. Accessed on 19 May 2002.

6. LCDC. Influenza in Canada: 1998-1999 Season. Canada Communicable Disease Report 1999; 25-22: 185- 191.

7. Monto AS, Gravenstein S, Elliot M, Colopy M, Schweinle J. Clinical signs and symptoms predicting influenza infection. Arch Intern Med 2000; 160(21): 3243-3247.

8. Kelly $\mathrm{H}$, Murphy $\mathrm{A}$, Leong $\mathrm{W}$, et al. Laboratory-supported influenza surveillance in Victorian sentinel general practices. Commun Dis Intell 2000; 24(12): 379-383.

9. WHO. Influenza case definition. Available from <http://www.who.int/emcdocuments/surveillance/docs/ whocdscsrisr992.html/15Influenza.htm>. Accessed on 20 May 2002.

10. Classification Committee of WONCA. ICHPPC-2- Defined: Inclusion Criteria for the Use of the Rubrics of the International Classification of Health Problems in Primary Care. New York, NY: Oxford University Press Inc, 1983, p. 487.

11. European Commission Directorate-General 'Health \& Consumer Protection'. Decision No 2119/98/EC of the European Parliament and of the Council of 24 September 1998: setting up a network for epidemiological surveillance and control of communicable diseases in the community. Official J Eur Commun 1998; L268-1- L268/7.

12. Pel JZS. Proefonderzoek naar de frequentie en de aetiologie van griepachtige ziektebeelden in de winter 1963-1964. Huisarts en Wetenschap 1965; 8: 321- 324.

13. Uphoff $\mathrm{H}$, Cohen J-M, Fleming D, Noone A. Reporting of influenza surveillance morbidity data from an international European surveillance scheme: A simple index. Options for the control of influenza IV conference, Hersonissos, Crete, Greece, 23-28 September 2000, Abstract P124.

Address for correspondence: Dr Jean-Franc, ois Aguilera, Respiratory Division, CDSC, PHLS, 61 Colindale Avenue, London, United Kingdom Phone: +44-207-2818864; Fax: +44-207-2817868 E-mail: jaguilera@phls.org.uk 